UHERO

THE ECONOMIC RESEARCH ORGANIZATION AT THE UNIVERSITY OF HAWAI'I

\section{THE DIRECT AND INDIRECT CONTRIBUTIONS OF TOURISM TO REGIONAL GDP: HAWAII}

BY

EUgene TIAN, JAMES MAK, AND PINGSUN LeUNG

Working Paper No. 2011-5

July 28, 2011 


\title{
The Direct and Indirect Contributions of Tourism to Regional GDP: Hawaii
}

\author{
Eugene Tian, James Mak, and PingSun Leung ${ }^{1}$
}

\begin{abstract}
After two decades of development and refinement, the Tourism Satellite Account (TSA) has been touted as the most comprehensive way to measure the economic contribution of tourism to a destination's gross domestic product. However, recent literature has pointed out that the TSA is deficient in that it does not yield the indirect contribution of tourism to GDP. This paper shows that the TSA cannot be used to estimate the indirect contribution unless the import content of tourism is zero. The indirect contribution can be estimated using input-output (I-O) multipliers. We illustrate using Hawaii as an example.
\end{abstract}

Keywords: tourism satellite account, I-O analysis, tourism GDP, Hawaii

\section{Introduction}

Tourism is not officially defined as an industry; its output is embedded in various standard industries. For that reason, it had been difficult to measure the size of its separate contribution to a country's or region's economy. The development of the tourism satellite account (TSA) more than two decades ago has been hailed as an important step in advancing our knowledge of the economic contributions of tourism. Frechtling, in his keynote address to the Fifth UNWTO International Conference on Tourism Statistics in 2009 and in his recent (2010, p. 136) primer on TSA notes that TSA is a "method of measuring the direct contributions of tourism consumption to a national economy." The unique feature of the TSA is that it "derives from its nature as an account rather than a model and its observance of the principles of national economic accounting." In 2008 the World Tourism Organization (UNWTO) issued two publications that provide a detailed documentation of its methodology. The 2011 Edition of the UNWTO Tourism Highlights states (p.

2) that "The most comprehensive way to measure the economic importance of both inbound and

\footnotetext{
${ }^{1}$ Eugene Tian, State Economist, Research and Economic Analysis Division, Department of Business, Economic Development and Tourism, State of Hawaii. James Mak, Professor Emeritus of Economics and Research Fellow, University of Hawaii Economic Research Organization, University of Hawaii at Manoa. PingSun Leung, Professor of Agricultural and Resource Economics, Department of Natural Resources and Environmental Management, University of Hawaii at Manoa. Senior authorship is not assigned.
} 
domestic tourism...is through the 2008 Tourism Satellite Account (TSA) Recommended Methodological Framework, approved by the UN Statistics Commission."

Recently doubts have been raised regarding TSA's ability to measure comprehensively the contribution of tourism to the gross domestic product (GDP) of an economy. Smeral (2011, p. 154) writes, "It should be considered that a major goal of the TSA project was to prevent the tourism industry from being dismissed as a minor economic player. Unfortunately, the TSA spans only those effects that are generated by the direct economic relationship between guest and producer and thus makes it difficult to compare tourism-related GDP in relation to the overall GDP, since the latter also includes indirect effects caused by economic linkages. Another problem arises from the fact that, in the TSA, expenditures from residents on business trips [which are generally considered to be intermediate consumption] are accounted for as final demand. On the other hand, intermediate consumption is not considered in GDP calculation, resulting in a biased comparison of the value added to GDP according to the TSA. It is clear that in measuring the TSA-based contribution made by the tourism industry to national/regional GDP, results must be adjusted for indirect effects and intermediate consumption." (The words in [ ] were added.)

The appropriate procedure to calculate tourism's direct and indirect contributions to GDP is to subtract out domestic business travel from tourism expenditures and treat it as intermediate purchase, then use the resulting expenditures to calculate the direct contribution of tourism to GDP. In a second step apply input-output (I-O) multipliers to tourism expenditures net of domestic business travel to derive the indirect effects. As we explain below, there is no other way to derive the direct and indirect effects by using the TSA alone unless the import content of tourism is zero.

In this article, we demonstrate the application of this two-step procedure to an open regional economy, Hawaii, to estimate the contribution of tourism--direct and indirect--to Hawaii's GDP. We were also motivated by the conclusions of a study done by Laney (2009) for the First Hawaiian Bank which used ad hoc Keynesian-type multipliers to show that tourism accounts for about 40 percent of Hawaii's GDP. The bank study has become the "bible" on the subject. We hoped to validate the bank's result using more rigorous methods. In our study, we find tourism's contribution to Hawaii's GDP to be significantly less than what was estimated by Laney. 


\section{Why Is It Necessary to Use I-0 to Estimate the Total Contribution of Tourism to}

GDP?

In his 2006 article, Smeral (2006) employed I-O multipliers to estimate the indirect contribution of tourism to GDP. Tourism's total (i.e. the direct and indirect) contribution can be derived directly and thus more simply from tourist expenditure data in the TSA without applying a second-step multiplier exercise as employed by Smeral, provided the import content of tourism expenditures is zero. To show this, we first examine the relationship between TSA and I-O.

Building the TSA account employs the same process as constructing the input-output (I-O) table. As in the I-O table, tourism demand in the TSA is presented in the supply and consumption account (Table 6 of the UNWTO TSA:RMF 2008). The differences between the TSA and the I-O table are: (1) TSA does not show the inter-industry transaction while the I-O table does; and (2) TSA includes business travel spending in the tourism demand column while the I-O table includes business travel spending in the inter-industry transaction section of the table. In other words, business travel is treated in the TSA as final demand but is treated as an intermediate good in the I$\mathrm{O}$ table. If we assume that there is no business travel spending, then the TSA account and the I-O table are basically the same. Moreover, if we assume that the import content of tourist expenditures is zero, then tourism demand is equal to tourism value-added. This derives from the well-known identity that GDP $=\mathrm{C}+\mathrm{I}+\mathrm{G}+(\mathrm{X}-\mathrm{M})$, where $\mathrm{C}$ is household consumption spending, I is investment spending, $\mathrm{G}$ is government spending on goods and services, and (X-M) is net exports. For the sake of simplicity, we can assume all tourism spending $\left(\mathrm{X}_{\mathrm{t}}\right)$ is in $\mathrm{X}$. If the import content of tourism spending is zero, then $M_{t}=0$ and $\left(X_{t}-M_{t}\right)$, is equal to $X_{t} . X_{t}$ is tourism's contribution to GDP, or tourism value-added.

Many TSAs are constructed from I-O tables. Actually, there are two types of I-O models in use. The first I-O type is the Leontief I-O model, which was initially formulated by Wassily Leontief in the 1930s (Leontief, 1936). In the Leontief model, an industry produces only one commodity. It is referred to as the industry-by-industry model. The second model was introduced by the United Nations in 1968 (United Nations, 1968). This model extends the Leontief model by allowing industries to produce more than one commodity. This model requires the construction of a "Make" table and a "Use" table so that this I-O model is often referred to as the make-use model. About half the I-O models in the world are Leontief type industry-by-industry I-O models (Guo, 
Lawson, and Planting, 2003). The UNWTO TSA account is similar to the make-use I-O model, as is the U.S. TTSA.

Accepting the notion that simplicity is a virtue, we pick the simpler industry-by-industry IO model to demonstrate that our (call it the direct) approach using expenditure information contained in the TSA and Smeral's (call it the indirect) approach using a second-step I-O multiplier exercise to estimate tourism's indirect effects, yield the same value-added for tourism for any given level of tourism expenditure without imports. It requires little additional effort to substantiate our claim using a more complicated make-use I-O model.

We assume the economy has two industries, and each produces a single commodity. There are no domestic business travel and imports. Since TSA starts with tourism final demand, we separate the final demand into tourist and non-tourist expenditures. In Table 1, Industry 1 has final demand of $\$ 10$ million of which $\$ 2$ million are attributed to "tourists" and the remaining $\$ 8$ million are attributed to "non-tourists". Industry 1 also has an intermediate demand of \$5 million, making its total output of $\$ 15$ million. Likewise, Industry 2 has tourism final demand of $\$ 2$ million, total final demand of \$12 million, \$9 million in intermediate demand, and total output of \$21 million. All of these numbers are arbitrarily selected. The "value- added" in Industry 1 is $\$ 9$ million, and $\$ 13$ million in Industry 2. In this economy, total tourism final demand is $\$ 4$ million.

Table 1. A simple I-O model with two industries without imports

(Millions of dollars)

\begin{tabular}{lcccccc}
\hline & & & Intermediate & \multicolumn{2}{c}{ Final demand } & \\
\cline { 5 - 6 } \multicolumn{1}{c}{ Industry } & Industry 1 & Industry & Demand & Non-Tourist & Tourist & Total output \\
\hline Industry 1 & 2 & 3 & 5 & 8 & 2 & 15 \\
Industry 2 & 4 & 5 & 9 & 10 & 2 & 21 \\
Value added & 9 & 13 & & & & \\
Total Input & 15 & 21 & & & & \\
\hline
\end{tabular}

From Table 1, tourism's shares of total outputs in Industries 1 and 2 are respectively 0.133 (=\$2 million $/ \$ 15$ million) and 0.095 (=\$2 million $/ \$ 21$ million). In Industry 1 , the ratio of its value 
added to its total output is 0.6 (=\$9 million $/ \$ 15$ million), and in Industry 2 it is 0.619 (=\$13 million $/ \$ 21$ million). Then total value added attributable to tourism is simply $\$ 2.438$ million ( $=\$ 2$ million $\times 0.6+\$ 2$ million $\times 0.619$ ). The $\$ 2.438$ million figure is commonly referred to in TSAs as tourism's direct contribution to GDP, or "direct tourism GDP”.

However, we know from national income accounting that tourism's total contribution to GDP is actually $\$ 4$ million (i.e. tourism's final demand) and not $\$ 2.438$ million (recall that the import content of tourism is assumed to be zero). What are missing in the $\$ 2.438$ million number are the indirect effects. Smeral suggests that the indirect effects can be calculated by applying a second-step multiplier exercise. We can show that he is correct.

1. First we determine the technical coefficient matrix A as $A=\left(\begin{array}{cc}2 / 15 & 3 / 21 \\ 4 / 15 & 5 / 21\end{array}\right)$;

2. Next, we determine the total requirement matrix (Leontief Inverse) as

$$
(I-A)^{-1}=\left(\begin{array}{ll}
1.224 & 0.230 \\
0.429 & 1.393
\end{array}\right)
$$

3. Total output due to tourism demand for Industries 1 and 2 respectively would then be $(I-A)^{-1}\left(\begin{array}{l}2 \\ 2\end{array}\right)=\left(\begin{array}{l}2.908 \\ 3.643\end{array}\right)$

4. Finally, value-added due to tourism demand for industries 1 and 2 respectively can be calculated as $\$ 1.745 \mathrm{~m}(=2.908 \times 0.600)$ and $\$ 2.255 \mathrm{~m}(=3.643 \times 0.619)$. Or, total value-added is exactly $\$ 4 \mathrm{~m}(=\$ 1.745 \mathrm{~m}+\$ 2.255 \mathrm{~m})$.

The $\$ 4$ million figure for tourism value-added derived by applying I-O multipliers to tourist expenditures is exactly the same number as the $\$ 4$ million figure for tourism final demand in Table 1. In other words, if we already know the tourists' expenditures ( $\$ 4$ million in our example), that is tourism's direct and indirect contribution to GDP (again, recall that we assumed no imports). In the absence of imports, tourism's direct and indirect contribution to GDP can be calculated from information contained in the TSA; it is unnecessary to apply I-O multipliers in a second stage to derive the indirect effects. To be sure, in real world application, knowing tourists' expenditures alone does not yield tourism value-added, as the issue of the import content of tourist expenditures still must be addressed.

Once we introduce imports, it is no longer possible to estimate tourism's indirect contribution to GDP using the TSA. While $\mathrm{M}$ is known in the expenditure equation of GDP, $\mathrm{M}_{\mathrm{t}}$ is not available from the TSA. It should be noted that total imports $M$ includes imports for final 
consumption $\left(\mathrm{M}_{\mathrm{f}}\right)$, import contents of final demand $\left(\mathrm{M}_{\mathrm{d}}\right.$, "direct" import contents) as well as import contents of intermediate goods and services required to deliver final demand to the economy $\left(\mathrm{M}_{\mathrm{i}}\right.$, "indirect" import contents). Likewise, imports related to tourism expenditures, $\mathrm{M}_{\mathrm{t}}$, also include three components - imports consumed directly by tourists $\left(\mathrm{M}_{\mathrm{tf}}\right)$, import content of goods and services consumed by tourists $\left(\mathrm{M}_{\mathrm{td}}\right)$, and the import content of intermediate goods and services required to deliver the final goods and services consumed directly by the tourists $\left(\mathrm{M}_{\mathrm{ti}}\right)^{2} . \mathrm{M}_{\mathrm{f}}$ and $\mathrm{M}_{\mathrm{d}}$ are usually presented collectively in a TSA table, and as a result, $\mathrm{M}_{\mathrm{tf}}$ and $\mathrm{M}_{\mathrm{td}}$ can be derived collectively in the TSA using the import ratio of each goods and services in the economy. Unfortunately, $\mathrm{M}_{\mathrm{ti}}$ cannot be uncovered from the TSA because the TSA does not show interindustry relationships; I-O does. Thus, with imports, we are no longer able to derive the tourism GDP ( $\left.=\mathrm{X}_{\mathrm{t}}-\mathrm{M}_{\mathrm{tf}}-\mathrm{M}_{\mathrm{td}}-\mathrm{M}_{\mathrm{ti}}\right)$ directly from the TSA without knowing $\mathrm{M}_{\mathrm{ti}}$. Hence, to calculate the indirect contribution of tourism to GDP, it is necessary to resort to an I-O manipulation. We illustrate this by using Hawaii as an example (below).

\section{The Direct Contribution of Tourism to Hawaii's GDP}

In this section, we develop a tourism satellite account for Hawaii (HITSA) for 2010 to derive the direct contribution of tourism to Hawaii's GDP. We begin with tourism consumption in Hawaii. Tourism consumption in HITSA includes travel related expenditures within Hawaii by its own residents as well as by out-of-state visitors. The expenditure categories for this study include out-of-state visitor expenditures, overseas airline spending in Hawaii, out-of-state cruise line spending in Hawaii, Hawaii residents' interisland travel for leisure, business, and visiting friends and relatives, and travel by Hawaii government employees on official business. More details are provided in Appendix A.

\footnotetext{
${ }^{2} \mathrm{M}_{\mathrm{tf}}$ refers to goods sold directly to the tourists - a souvenir coffee cup made in China and imported for direct sale to tourists. In this case, the transportation, wholesale and retail margins are allocated to the respective industries and only the FOB value is recorded in $\mathrm{M}_{\mathrm{tf}} \cdot \mathrm{M}_{\mathrm{td}}$ refers to the import content of the goods and services purchased directly by the tourists - an Aloha shirt with material imported from China but the shirt is made in Hawaii. Finally $\mathrm{M}_{\mathrm{ti}}$ refers to the import content of the goods and services to support the delivery of the goods and services purchased directly by the tourists - the imported oil to generate the electricity used by the garment factory for making an Aloha shirt.
} 
Although it is claimed that the TSA is an account rather than a model, building the account employs the same process as constructing the I-O table. The TSA framework recommended by the UNWTO consists of 12 tourism commodities and 10 statistical tables. The basic data for the HITSA is the Hawaii State Input-Output (I-O) table which has the production account readily available. Hawaii's Input-Output table is an industry-by-industry table; each industry produces a "representative" commodity.

For demonstration purposes, the actual HITSA is aggregated into five tourism industries and one "all others" sector (Table 2). A tourism industry is defined as one that would cease to exist without tourism or would continue to exist only at a significantly reduced level of activity. The "all others" represents commodities produced by non-tourism industries purchased by tourists. These commodities include groceries, gasoline, educational services, professional services, personal and laundry services, and health services. The UNWTO's TSA methodology excludes these commodities. However, both the U.S. and Canada's TSAs include them. We include them in the tourism sector for Hawaii. It is another source of downward bias when following the UNWTO's methodology. 
Table 2. Transaction table for Hawaii's tourism: 2010 (Millions of dollars)

\begin{tabular}{|c|c|c|c|c|c|c|c|c|c|}
\hline \multirow[b]{2}{*}{ Industry } & \multicolumn{7}{|c|}{ Industry } & \multirow[b]{2}{*}{ Final Demand } & \multirow[b]{2}{*}{ Total Output } \\
\hline & Transportation & Trade & $\begin{array}{l}\text { Accom. \& } \\
\text { Rentals }\end{array}$ & $\begin{array}{l}\text { Eating \& } \\
\text { Drinking }\end{array}$ & $\begin{array}{c}\text { Entertain } \\
\text { ment }\end{array}$ & $\begin{array}{l}\text { All } \\
\text { Others }\end{array}$ & $\begin{array}{c}\text { Total Intermediate } \\
\text { demand }\end{array}$ & & \\
\hline Transportation & 308.3 & 38.7 & 159.3 & 37.7 & 5.9 & 626.1 & $1,176.0$ & $4,665.9$ & $5,841.9$ \\
\hline Trade & 59.3 & 143.2 & 183.0 & 124.2 & 4.1 & $1,721.9$ & $2,235.8$ & $7,829.0$ & $10,064.8$ \\
\hline Accom. \& rentals & 136.6 & 933.5 & $1,410.0$ & 253.8 & 38.9 & $2,831.5$ & $5,604.4$ & $16,390.3$ & $21,994.7$ \\
\hline Eating \& Drinking & 42.2 & 47.2 & 59.8 & 37.6 & 8.0 & 366.0 & 561.0 & $3,026.1$ & $3,587.1$ \\
\hline Entertainment & 0.6 & - & 2.4 & 6.7 & 14.2 & 14.9 & 38.9 & 778.9 & 817.8 \\
\hline All others & $1,644.9$ & $1,420.3$ & $3,968.9$ & 825.5 & 111.1 & $11,880.6$ & $19,851.2$ & $47,627.1$ & $67,478.3$ \\
\hline Total Intermediate inputs & $2,192.0$ & $2,582.9$ & $5,783.5$ & $1,285.5$ & 182.3 & $17,441.0$ & $29,467.2$ & $80,317.3$ & $109,784.5$ \\
\hline Imports & 661.0 & 984.9 & 658.4 & 485.4 & 42.4 & $10,725.3$ & $13,557.3$ & $14,869.9$ & \\
\hline Value Added & $2,989.0$ & $6,497.0$ & $15,552.8$ & $1,816.2$ & 593.0 & $39,312.0$ & $66,760.0$ & & \\
\hline Output & $5,841.9$ & $10,064.8$ & $21,994.7$ & $3,587.1$ & 817.8 & $67,478.3$ & $109,784.5$ & & \\
\hline
\end{tabular}


Table 2 provides more information than the typical TSA production account. It is an abridged version of the Hawaii's I-O model showing only the tourism industries. Reading across a row shows sales by the row industry to the various column industries and final consumption. Reading down a column shows the purchases by the column industry from the various row industries.

The supply and consumption relations are presented in Table 3. This table is the industrybased version of the TSA. Appendix B shows the standard commodity-based version of the Hawaii TSA. Since Hawaii's I-O model is an industry-by-industry table, the industry-based version of Hawaii TSA provides a more direct comparison between the I-O and TSA. In 2010, tourism consumption in Hawaii totaled $\$ 14.7$ billion; of that nearly $\$ 13.1$ billion can be attributed to out-of-state visitors, airlines and cruise lines. The rest comprises of spending by local businesses, residents, and state and local governments on travel in Hawaii.

To calculate "direct tourism GDP”, we employed the ratio of tourism consumption to total consumption for each industry (the ratio is assumed to be the same for everyone, tourists or nontourists). The six tourism industries (including "all others") and their tourism industry ratios for 2010 are presented in Table 4. The tourism industry ratio (or column C) represents the percentage of the total sales of the industry that goes to (i.e. sold to/ purchased by) tourists. For example, Table 4 (column $\mathrm{D}$, row 1$)$ shows that 52 percent $(=\$ 3,061.1 \mathrm{million} / \$ 5,841.9$ million $\mathrm{x} 100$ from Table 3) of air transportation industry's sales went to tourists in 2010. 
Table 3. Consumption table for Hawaii's TSA: 2010 (Millions of dollars)

\begin{tabular}{|c|c|c|c|c|c|c|c|c|c|c|c|c|}
\hline \multirow{3}{*}{ Industry } & \multicolumn{4}{|c|}{ Supply } & \multicolumn{7}{|c|}{ Consumption } & \multirow{3}{*}{$\begin{array}{c}\text { Total } \\
\text { consumptio }\end{array}$} \\
\hline & \multirow[b]{2}{*}{$\begin{array}{l}\text { Domestic } \\
\text { production }\end{array}$} & \multirow[b]{2}{*}{$\begin{array}{l}\text { Imports for } \\
\text { intermediate } \\
\text { Use }\end{array}$} & \multirow[b]{2}{*}{ Total } & \multicolumn{5}{|c|}{ Tourism Consumption } & \multicolumn{3}{|c|}{ Non-Tourism Consumption } & \\
\hline & & & & $\begin{array}{c}\text { Business } \\
\text { travel } \\
\text { (Intermediate) }\end{array}$ & $\begin{array}{c}\text { Resident } \\
\text { household }\end{array}$ & $\begin{array}{c}\text { Governm } \\
\text { ent }\end{array}$ & $\begin{array}{l}\text { Out-of-state } \\
\text { visitor, airline, } \\
\text { and cruise line } \\
\text { expenditures }\end{array}$ & Total & Intermediate & $\begin{array}{r}\text { Final } \\
\text { demand }\end{array}$ & Total & \\
\hline Transportation & $5,180.9$ & 661.0 & $5,841.9$ & 260.5 & 495.6 & 29.7 & $2,275.3$ & $3,061.1$ & 915.5 & $1,865.3$ & $2,780.8$ & $5,841.9$ \\
\hline Trade & $9,079.9$ & 984.9 & $10,064.8$ & 22.2 & 42.6 & - & $1,390.0$ & $1,454.9$ & $2,213.6$ & $6,396.4$ & $8,609.9$ & $10,064.8$ \\
\hline Accom. \& rentals & $21,336.3$ & 658.4 & $21,994.7$ & 199.9 & 310.6 & 12.8 & $5,536.9$ & $6,060.2$ & $5,404.5$ & $10,530.0$ & $15,934.5$ & $21,994.7$ \\
\hline Eating \& Drinking & $3,101.7$ & 485.4 & $3,587.1$ & 15.3 & 41.9 & 2.3 & $1,336.6$ & $1,396.0$ & 545.7 & $1,645.3$ & $2,191.1$ & $3,587.1$ \\
\hline Entertainment & 775.3 & 42.4 & 817.8 & 2.1 & 16.1 & 0.2 & 332.4 & 350.8 & 36.7 & 430.3 & 467.0 & 817.8 \\
\hline All others & $56,753.1$ & $10,725.3$ & $67,478.3$ & - & - & - & 706.9 & 706.9 & $19,851.2$ & $46,920.2$ & $66,771.5$ & $67,478.3$ \\
\hline Total & $96,227.2$ & $13,557.3$ & $109,784.5$ & 500.0 & 906.8 & 45.0 & $11,578.0$ & $13,029.8$ & $28,967.2$ & $67,787.6$ & $96,754.8$ & $109,784.5$ \\
\hline Imports for final use & & & & & 143.2 & & $1,562.2$ & $1,705.4$ & & $13,164.5$ & $13,164.5$ & $14,869.9$ \\
\hline Total & $96,227.2$ & $13,557.3$ & $109,784.5$ & 500.0 & $1,050.0$ & 45.0 & $13,140.2$ & $14,735.2$ & $28,967.2$ & $80,952.0$ & $109,919.3$ & $124,654.5$ \\
\hline
\end{tabular}

Source: Authors' Estimates based on Hawaii Department of Business, Economic Development \& Tourism, 2007 Hawaii State Input-Output model. 
Table 4. Direct contribution of Hawaii's tourism to GDP: 2010 (Millions of dollars)

\begin{tabular}{|c|c|c|c|c|c|c|}
\hline Industry & $\begin{array}{c}\text { Total } \\
\text { consumption }\end{array}$ & $\begin{array}{c}\text { Tourism } \\
\text { consumption }\end{array}$ & $\begin{array}{l}\text { Tourism } \\
\text { ratio }\end{array}$ & $\begin{array}{l}\text { Total } \\
\text { intermediate } \\
\text { inputs }\end{array}$ & $\begin{array}{c}\text { Tourism } \\
\text { intermediate } \\
\text { consumption }\end{array}$ & $\begin{array}{c}\text { Tourism } \\
\text { value } \\
\text { added }\end{array}$ \\
\hline A & $\begin{array}{l}\text { B: from } \\
\text { Table } 3\end{array}$ & $\begin{array}{l}\text { C:from } \\
\text { Table } 3\end{array}$ & $D=C / B$ & $\begin{array}{l}\text { E: from } \\
\text { Table } 2\end{array}$ & $\mathrm{~F}=\mathrm{D} \times \mathrm{E}$ & $\mathrm{G}=\mathrm{C}-\mathrm{F}$ \\
\hline Transportation & $5,841.9$ & $3,061.1$ & 0.52 & $2,852.9$ & $1,494.88$ & $1,566.2$ \\
\hline Trade & $10,064.8$ & $1,454.9$ & 0.14 & $3,567.8$ & 515.72 & 939.1 \\
\hline Accom. \& rentals & $21,994.7$ & $6,060.2$ & 0.28 & $6,441.8$ & $1,774.93$ & $4,285.3$ \\
\hline Eating \& drinking & $3,587.1$ & $1,396.0$ & 0.39 & $1,770.9$ & 689.20 & 706.8 \\
\hline Entertainment & 817.8 & 350.8 & 0.43 & 224.8 & 96.40 & 254.4 \\
\hline All others & $67,478.3$ & 706.9 & 0.01 & $28,166.3$ & 295.06 & 411.8 \\
\hline TOTAL & $109,784.5$ & $13,029.8$ & 0.12 & $43,024.5$ & $4,866.2$ & $8,163.6$ \\
\hline
\end{tabular}

The "direct tourism GDP" or tourism's direct contribution to Hawaii's GDP is displayed in the last column $(\mathrm{G})$ of Table 4 . It is the sum of the tourism value-added by each of the six tourism industries, or nearly $\$ 8.2$ billion. Tourism value-added is the difference between tourism output and tourism intermediate consumption (column $\mathrm{C}$ minus column F). For example, Table 4 (column $\mathrm{C}$, row 3) shows that the accommodations industry sold nearly $\$ 6.1$ billion in rentals to tourists in Hawaii in 2010; after subtracting nearly $\$ 1.8$ billion of intermediate purchases (Table 4, column F, row 3) such as utilities, etc. from other industries, the value-added of this industry was $\$ 4.3$ billion. For all six tourism industries, tourism value-added in 2010 totaled nearly $\$ 8.2$ billion. The important observation is that the $\$ 8.2$ billion is significantly less than the total amount of money spent on tourism consumption ( $\$ 14.7$ billion). Much of the difference can be attributed to the exclusion of tourism's indirect contribution to GDP as we explain in the next section. 


\section{Using I-0 Multipliers to Derive Indirect Contribution of Tourism}

From Table 5, we see that total adjusted tourism spending-i.e. tourism spending after netting out business travel-- is $\$ 14.235$ billion $(=\$ 14.735$ - $\$ 0.500$ billion). Imports for tourism final consumption, $\mathrm{M}_{\mathrm{t} f}$, is $\$ 1.705$ billion (Column $\mathrm{B}$, row 8). The import content of tourism final demand, $\mathrm{M}_{\mathrm{td}}$, can be calculated using the import ratios of the tourism final demand as shown in Table 5; $\mathrm{M}_{\mathrm{td}}$ is found to be $\$ 0.950$ billion.

Table 5. Direct import content of tourism consumption: 2010 (Millions of dollars)

\begin{tabular}{|c|c|c|c|c|c|}
\hline & $\begin{array}{l}\text { Total tourism } \\
\text { consumption }\end{array}$ & Business travel & $\begin{array}{l}\text { Adjusted tourism } \\
\text { consumption }\end{array}$ & Import ratio & $\begin{array}{l}\text { Import } \\
\text { content }\end{array}$ \\
\hline A & B: from Table 3 & C: from Table 3 & $D=B-C$ & $\begin{array}{l}\text { E: Calculated } \\
\text { from Table } 3\end{array}$ & $\mathrm{~F}=\mathrm{D} \times \mathrm{E}$ \\
\hline Transportation & $3,061.1$ & 260.5 & $2,800.6$ & 0.113 & 316.9 \\
\hline Trade & $1,454.9$ & 22.2 & $1,432.6$ & 0.098 & 140.2 \\
\hline Accom. \& rentals & $6,060.2$ & 199.9 & $5,860.3$ & 0.030 & 175.4 \\
\hline Eating \& Drinking & $1,396.0$ & 15.3 & $1,380.8$ & 0.135 & 186.8 \\
\hline Entertainment & 350.8 & 2.1 & 348.6 & 0.052 & 18.1 \\
\hline All others & 706.9 & - & 706.9 & 0.159 & 112.4 \\
\hline Sub-Total & $13,029.8$ & 500.0 & $12,529.8$ & & 949.7 \\
\hline Imports for final use & $1,705.4$ & & $1,705.4$ & & \\
\hline Total & $14,735.2$ & 500.0 & $14,235.2$ & & \\
\hline
\end{tabular}

However, we are unable to estimate $\mathrm{M}_{\mathrm{ti}}$--the import content of intermediate goods and services --from the TSA. In other words, we are able to extract $\mathrm{M}_{\mathrm{tf}}$ and $\mathrm{M}_{\mathrm{td}}$ from the TSA but not $\mathrm{M}_{\mathrm{ti}}$; thus, we are unable to calculate tourism's total (i.e. direct plus indirect) contribution to GDP from expenditure information contained in the TSA alone. 
One way to uncover $\mathrm{M}_{\mathrm{ti}}$ is to use the import multipliers available through the I-O model. Import multipliers ${ }^{3}$ provide the direct and indirect imports necessary to deliver a dollar worth of goods and services for final consumption (final demand). Table 6 shows that the total (direct and indirect) imports necessary to support tourism final demand amounts to $\$ 1.599$ billion. Therefore, $\mathrm{M}_{\mathrm{ti}}$ can be estimated as $\$ 0.649$ billion (=\$1.599 - $\$ 0.950$ billion). Finally, tourism GDP can now be estimated as $\$ 10.931$ billion (= \$14.735b. - \$0.500b. - \$1.705b. - \$0.950b. - \$0.649b.).

Table 6. Direct and indirect import content of tourism consumption: 2010 (Millions of dollars)

\begin{tabular}{lrcr}
\hline & $\begin{array}{c}\text { Adjusted } \\
\text { tourism } \\
\text { consumption }\end{array}$ & Import multiplier & $\begin{array}{c}\text { Direct and indirect import } \\
\text { content }\end{array}$ \\
\hline A & B: from Table 5 & C:from I-O calculation & D=B×C \\
\hline Transportation & $2,800.6$ & 0.185 & 518.1 \\
Trade & $1,432.6$ & 0.137 & 196.6 \\
Accom \& rentals & $5,860.3$ & 0.075 & 437.3 \\
Eating \& Drinking & $1,380.8$ & 0.197 & 271.4 \\
Entertainment & 348.6 & 0.089 & 30.9 \\
All others & 706.9 & 0.204 & 144.5 \\
Sub-Total & $12,529.8$ & & $1,598.8$ \\
Imports for final use & $1,705.4$ & & $1,705.4$ \\
Total & $14,235.2$ & & $3,304.2$ \\
\hline
\end{tabular}

Alternatively, we can derive total tourism GDP using the value-added multipliers from the I-O model. Similar to import multipliers, value-added multipliers ${ }^{4}$ provide the direct and indirect value-added associated with the delivery of a dollar worth of goods and services for final consumption. Table 7 shows that the total value-added of tourism to GDP is $\$ 10.931$ billion, which is the same as that derived by subtracting the three tourism related imports from final tourism expenditures. This leads to an important observation that is often overlooked; that is, the value of tourism's net exports (i.e. tourism's final expenditures minus tourism related imports)

\footnotetext{
${ }^{3}$ Import multiplier can be derived as follows: $i(I-A)^{-1}$, where $i$ is the row vector of import coefficients (ratios), i.e., the import share per unit of output; and $(I-A)^{-1}$ is the traditional Leontief total requirement matrix.

${ }^{4}$ Similarly, value-added multiplier can be derived as follows: $V(I-A)^{-1}$, where $V$ is the row vector of value-added coefficients, i.e., the value-added share per unit of output; and $(I-A)^{-1}$ is the traditional Leontief total requirement matrix.
} 
includes tourism's direct and indirect contributions to a country/region's GDP. These results also indicate that one dollar of final tourism spending generates (directly and indirectly) less than one dollar of GDP in Hawaii.

Table 7. Total value-added (GDP) of tourism: 2010 (Millions of dollars)

\begin{tabular}{lccr}
\hline Industry & $\begin{array}{c}\text { Adjusted tourism } \\
\text { consumption }\end{array}$ & $\begin{array}{c}\text { Value-added } \\
\text { multiplier }\end{array}$ & $\begin{array}{c}\text { Direct and indirect } \\
\text { value-added }\end{array}$ \\
\hline A & B: from Table 6 & $\begin{array}{c}\text { C:from I-O } \\
\text { calculation }\end{array}$ & D=B×C \\
\hline Transportation & $2,800.6$ & 0.815 & $2,282.4$ \\
Trade & $1,432.6$ & 0.863 & $1,236.1$ \\
Accom. \& rentals & $5,860.3$ & 0.925 & $5,423.0$ \\
Eating \& Drinking & $1,380.8$ & 0.803 & $1,109.4$ \\
Entertainment & 348.6 & 0.911 & 317.7 \\
All others & 706.9 & 0.796 & 562.4 \\
Sub-Total & $12,529.8$ & & $10,931.0$ \\
Imports for final use & $1,705.4$ & & \\
Total & $14,235.2$ & & \\
\hline
\end{tabular}

\section{Summary of Findings and Conclusion}

The tourism satellite account has been used in over 70 countries to measure the contribution of tourism to national economies (Aydin, 2008). It has also been criticized for its failure to capture more fully tourism's contribution to a destination's GDP. The TSA typically only displays tourism's direct contribution to GDP and not its indirect contribution. We show that the TSA cannot be used to generate the indirect contribution of tourism to GDP when there are imports. The only practical solution is to apply input-output multipliers in a second step manipulation to generate the indirect effects. In addition, travel expenditures by local businesses within the destination, which are treated as final demand in the TSA, must first be netted out.

Using Hawaii as an example, in 2010, total tourism spending by Hawaii's residents and out-of-state visitors in Hawaii totaled $\$ 14.735$ billion. Subtracting domestic business travel spending of \$500 million (to exclude intermediate goods) yields tourism final demand in Hawaii of $\$ 14.235$ billion. Tourism related imports were $\$ 3.304$ billion, or about 23 cents for every dollar of 
final tourism expending in Hawaii. The difference between the two figures ( $\$ 14.235$ billion minus $\$ 3.304$ billion) yields tourism's direct and indirect contribution of \$10.931 billion to Hawaii's 2010 GDP (valued at $\$ 66.760$ billion). From these numbers, it is clear that making the two adjustments suggested by Smeral — one to exclude resident business travel spending and the other to estimate tourism's indirect contributions to GDP-yields a more comprehensive measure of tourism's contribution to Hawaii's economy. Tourism's direct contribution to Hawaii's GDP in 2010 was $\$ 8.2$ billion; but a more accurate picture of its contribution was $\$ 10.931$ billion, a difference of thirty-three percent. In 2010, tourism-which in our study includes both inbound and domestic tourism-(directly and indirectly) comprised 16.4 percent of Hawaii's gross domestic product. If we include the induced effects, the percentage rises to 22 percent, or slightly more than half of Laney's estimate of 40 percent even though our number includes domestic (i.e. Hawaii resident) spending on travel and tourism within the state and Laney's does not.

Finally, one of the things we learned from this exercise is that if a destination already has an I-O table, it does not need a TSA to estimate the contribution of tourism to GDP. 


\section{References}

Aydin, N (2008). The need for tourism satellite accounts: a Florida case study. Applied Research in Economic Development, 5(3), 38-48.

Frechtling, D (2009). Clarifying and extending the TSA brand. Keynote, Session V: Measuring the economic contributions of Tourism: from the TSA to Alternative Modeling Techniques. Fifth UNWTI International Conference on Tourism Statistics, Bali, Indonesia, 30 March - 2 April 2009.

Frechtling, D (2010). The tourism satellite account, a primer. Annals of Tourism Research, 37(1), 136-153.

Guo, J, AM Lawson, and MA Planting (2003). From Make-Use to Symmetric l-O Tables: An Assessment of Alternative Technology Assumptions. Paper presented at the $11^{\text {th }}$ Inforum World Conference, Suzdal, Russa, September 8-12, 2003.

Hawaii State Department of Business, Economic Development \& Tourism (2011). The Hawaii State Input-Output Study: 2007 Benchmark Report. Honolulu, Hawaii, USA.

Laney LO (2009). Assessing tourism's contribution to the Hawaii economy. Economic Forecast, Special Report. Honolulu: First Hawaiian Bank.

Leontief W (1936). Quantitative input-output relations in the economic system of the Untied States. Review of Economics and Statistics,18(3), 105-125.

Smeral, E (2006). Tourism satellite accounts: a critical assessment. Journal of Travel Research, 45(1), 92-98.

Smeral, E (2011). Theory, econometrics, and bridge building in economics, in Larry Dwyer, editor, The Discovery of Tourism Economics, Tourism Social Science Series, Volume 16, Bingley, UK: Emerald Group Publishing, Ltd., pp. 147-158.

United Nations (1968). A System of National Accounts, New York, United Nations.

United Nations and World Tourism Organization (2008). International Recommendations for Tourism Statistics (IRTS 2008), New York, USA and Madrid, Spain.

United Nations Statistics Division (UNSD), the Statistical Office of the European Communities (EUROSTAT), the Organization for Economic Co-operation and Development (OECD) and the World Tourism Organization (UNWTO) (2008). 2008 Tourism Satellite Account: Recommended Methodological Framework (TSA: RMF 2008), Madrid, Spain. 
World Tourism Organization (2008), Measuring tourism: The UN-TSA approach vs the WTTC approach. Report prepared by the Department of Statistics and Tourism Satellite Account (TSA), Madrid, Spain.

World Tourism Organization (UNWTO) (2011). UNWTO Tourism Highlights, 2011 Edition, Madrid: UNWTO. 


\section{Appendix A}

\section{Data for Hawaii TSA}

Expenditures of tourists are the principal data used in calculating tourism consumption in the HITSA. Expenditures represent the amount of money paid to purchase consumption goods and services before, during, and after a trip; this includes valuables for personal use or gifts. Additionally, expenditures by tourists themselves as well as expenses that are paid for or reimbursed by others are counted as expenditures. The expenditure categories for this study include: out-of-state visitor expenditures; overseas airline spending in Hawaii; out-of-state cruise line spending in Hawaii; Hawaii residents traveling interisland for leisure, business, and visiting friends and relatives; and Hawaii government employees traveling on government business.

Data on out-of-state visitor expenditures are collected by the State of Hawaii through intercept surveys at all the passenger airports in Hawaii for air visitors, and on-board surveys for all cruise ships touring the Hawaiians islands. For visitors arriving by air, trans-Pacific airfare is not included in the visitor expenditures survey. For cruise visitors arriving on non-U.S. flagged ships, the price of the cruise package (which usually covers airfare, room and board, entertainment, and activities on-board) is not included in visitor spending. Only their spending on-shore is counted.

Cruise line spending in Hawaii is included. Cruise lines purchase food, fuel, entertainment, and maintenance services, etc.. Cruise lines also hire shipping agents in Hawaii to manage their ship operations. Shipping agents are included in the sector of travel arrangement services in this study. Out-of-state cruise line spending was estimated based on the cruise line surveys conducted in 2008 by Hawaii Tourism Authority (HTA).

By contrast, spending by domestic cruise lines is not separately added because the price of the cruise and on-ship spending is taxed by the state and therefore included in the visitor expenditure numbers collected by the State. Similarly, interisland airfares are already included in visitor expenditures so that the spending by interisland airlines is not listed as a separate category to avoid double counting.

Overseas airline spending in Hawaii is included in tourism consumption. Overseas airlines include all the airlines that do not have a hub center in Hawaii such as Japan Airlines, Northwest, and United Airlines. These airlines have offices in Hawaii, purchase supplies in 
Hawaii, and hire Hawaii residents as employees. Overseas airline operations accounted for more than one third of the air transportation sector in Hawaii. For the purpose of this study, overseas airline spending is assumed to be equivalent to half of the price of a round trip ticket. This assumption effectively divides the cost of providing air transportation evenly between Hawaii and the originating destination.

Following the framework of TSA, interisland spending on travel by Hawaii residents for the purpose of leisure and business are included as part of tourism consumption. This includes residents' travel on vacation, visiting friends and relatives, and on private and government business. Travel spending by residents commuting interisland for work and resident spending on their own island of residence are not included as tourism consumption. Interisland spending by residents is estimated based on the interisland resident passenger count derived from the Hawaii Department of Transportation report, the HTA/DBEDT interisland visitor survey, and the Hawaii State Input-Output models. 


\section{Appendix B}

\section{Commodity-Based Hawaii TSA}

Table B1. Production of commodities by industry: Hawaii 2010

(Millions of dollars)

\begin{tabular}{|c|c|c|c|c|c|c|c|}
\hline \multirow[b]{2}{*}{ Commodity } & \multicolumn{7}{|c|}{ Industry } \\
\hline & Transportation & Trade & $\begin{array}{l}\text { Accom. \& } \\
\text { Rentals }\end{array}$ & $\begin{array}{l}\text { Eating \& } \\
\text { Drinking }\end{array}$ & Entertainment & All Others & Total \\
\hline Transportation & $5,180.9$ & & & & & & $5,180.9$ \\
\hline Accom \& rentals & - & & $21,336.3$ & & & & $21,336.3$ \\
\hline Eating \& Drinking & - & & & $3,101.7$ & & & $3,101.7$ \\
\hline Entertainment & - & & & & 775.3 & & 775.3 \\
\hline All others & - & $9,079.9$ & & & & $56,753.1$ & $65,832.9$ \\
\hline Industry output & $5,180.9$ & $9,079.9$ & $21,336.3$ & $3,101.7$ & 775.3 & $56,753.1$ & $96,227.2$ \\
\hline Intermediate purchase & $2,192.0$ & $2,582.9$ & $5,783.5$ & $1,285.5$ & 182.3 & $17,441.0$ & $29,467.2$ \\
\hline Value Added & $2,989.0$ & $6,497.0$ & $15,552.8$ & $1,816.2$ & 593.0 & $39,312.0$ & $66,760.0$ \\
\hline
\end{tabular}


Table B2. Supply and consumption of commodities: Hawaii 2010

(Millions of dollars)

\begin{tabular}{|c|c|c|c|c|c|c|c|c|c|c|c|c|c|}
\hline \multirow[b]{3}{*}{ Commodity } & \multicolumn{4}{|c|}{ Supply } & \multicolumn{8}{|c|}{ Consumption } & \multirow[b]{3}{*}{$\begin{array}{c}\text { Total } \\
\text { consumption }\end{array}$} \\
\hline & \multirow[b]{2}{*}{$\begin{array}{l}\text { Domestic } \\
\text { production }\end{array}$} & \multirow[b]{2}{*}{ Imports } & \multirow[b]{2}{*}{$\begin{array}{l}\text { Trade } \\
\text { margins }\end{array}$} & \multirow[b]{2}{*}{ Total } & \multicolumn{5}{|c|}{ Tourism Consumption } & \multicolumn{3}{|c|}{ Non-Tourism Consumption } & \\
\hline & & & & & $\begin{array}{l}\text { Business } \\
\text { travel } \\
\text { (Interme } \\
\text { diate) }\end{array}$ & $\begin{array}{l}\text { Resident } \\
\text { household }\end{array}$ & $\begin{array}{l}\text { Govern } \\
\text { ment }\end{array}$ & $\begin{array}{l}\text { Out-of-state } \\
\text { visitor, airline, } \\
\text { and cruise line } \\
\text { expenditures }\end{array}$ & Total & $\begin{array}{l}\text { Interme } \\
\text { diate }\end{array}$ & $\begin{array}{c}\text { Final } \\
\text { demand }\end{array}$ & Total & \\
\hline Transportation & $5,180.9$ & - & & $5,180.9$ & 260.5 & 495.6 & 29.7 & $2,275.3$ & $3,061.1$ & 915.5 & $1,865.3$ & $2,780.8$ & $5,841.9$ \\
\hline Accom. \& rentals & $21,336.3$ & - & & $21,336.3$ & 199.9 & 310.6 & 12.8 & $5,536.9$ & $6,060.2$ & $5,404.5$ & $10,530.0$ & $15,934.5$ & $21,994.7$ \\
\hline Eating \& Drinking & $3,101.7$ & - & & $3,101.7$ & 15.3 & 41.9 & 2.3 & 1,336.6 & $1,396.0$ & 545.7 & $1,645.3$ & $2,191.1$ & $3,587.1$ \\
\hline Entertainment & 775.3 & - & & 775.3 & 2.1 & 16.1 & 0.2 & 332.4 & 350.8 & 36.7 & 430.3 & 467.0 & 817.8 \\
\hline All others & $56,753.1$ & $28,427.2$ & $9,079.9$ & $94,260.1$ & 22.2 & 185.8 & - & $3,659.1$ & $3,867.1$ & $\begin{array}{r}22,064 . \\
8\end{array}$ & $66,481.1$ & $88,546.0$ & $92,413.0$ \\
\hline Total & $87,147.3$ & $28,427.2$ & $9,079.9$ & $124,654.4$ & 500.0 & $1,049.9$ & 45.0 & $13,140.2$ & $14,735.1$ & $\begin{array}{r}28,967 . \\
3\end{array}$ & $80,952.1$ & $109,919.3$ & $124,654.4$ \\
\hline
\end{tabular}

Source: Authors' Estimates based on Hawaii Department of Business, Economic Development \& Tourism, 2007 Hawaii State Input-Output model. 